あろうと思われるが，現行の討論時間では余りに短く 2 名の質問者にて制限を超過してしまった，別䇪での討議 は質疑当事者の判断により続けられるべき便法であり分 科なり，研究発表の機会の開催数の増加の検討を望むも のである。

\section{管理-2 被曝 II}

座長 後藤 勝正（荒尾市民病院）

236. デンタルトモグラフィーの撮影時における被曝線 量について

同愛記念病院

○細川 明男・虎渡 勇二・米道 成炤 小野 公之・植木 邦雄・加藤 利一

237. 腰椎側面撮影にお生殖腺防護具の考案

総合病院湘南病院 放射線科

○栗田 達夫・横山 英彦

平川 勝美 · 三堀 光雄

[目的]

女子生殖可能年舲者の, 腰椎側面撮影時に新ける, 生 殖腺線量の低減をはかるため, 確実に生殖腺を遮蔽でき る防護具を考案作成する。

[方法]

(1)遮蔽範囲決定のため Lateral X-P 100 例の計測デー 夕を求めた。(2)Hysterosal PG 50例より卵巣位置の計測 と体表との相関をみた。(3)遮蔽板の作成，(4)効果確認の ための線量測定，(5)臨床撮影使用の結果と判定.

[結果]

防護の基準は，体表上の骨盤腸骨の上前腸骨棘，以下 を確実に行なえばよひ，考案した防護具の效果は，線量 が使用前に比して1/15に減少した。臨床撮影の使用結果 の成績は，目的を達したもの，当初の60例におりて76.5 \%でその後の50例では90\%と向上した.

238. TLDによるX線撮影時における被曝線量について （特に生殖腺部付近について）

日本生命済生会付属日生病院

○山本 晴市·平木 元二. 村上 群二 西川 直三・八木 隆幸 · 石井 㳦子

X線撮影に㧍いて，各撮影部位に応じ適当に多重絞り で絞った照射野处，特に女性生殖腺部の被曝線量を知る ために被検者の皮膚表画被儤線量と, 基礎実験は照射野 内では, 水槽, 外では Mix-Dp 亡し, 人体等価にほぼ等 しい瑗さとして，照射野外を含鉛ゴム布で被覆した場合 と，しない場合の照射野辺縁から一定の距離の表面とそ の部の深部の各層における散乱線を, 極光 TLD, 素子は
MSO-S，ホルダFを用い測定した。胸部は適切な絞りを 用いるととにより，乙の散乱線は，TLDでも測定でき ない $0.1 \mathrm{mR}$ 以下で, 胆のう部は腹厚との関係が線量に 影響する. 照射野近傍の線量は，照射野外を被覆すると とによりほぼ30\%前後減少した。

\section{9. 昭和50年度におけるわが国の診療放射線技術者の 血球数について}

\section{国立公监衛生院 放射線衛生学部 遠藤 幸一・石坂 正網}

昭和50年 8 月に全国保健所, 国羙病院および国立療養 所に勤務する㟝療放射線技師の健康調査を行ない血液㭘 查について報告した。

保健所技師 965 名, WBC: $6,540 \pm 1,559 / \mathrm{mm}^{3}, \mathrm{RBC}$ : 470 万士 46 万 $/ \mathrm{mm}^{3}, \mathrm{Hb}: 15.1 \pm 1.2 \mathrm{~g} / \mathrm{d} l$, 国立技師 519 名, $6,420 \pm 1,581 / \mathrm{mm}^{3}, 463$ 万土 45 万 $/ \mathrm{mm}^{3}, 14.9 \pm 1.3$ $\mathrm{g} / \mathrm{d} l$.

以上の結果を得た。一般健康者亡比較するといずれも 有意な差が認められたが, 調查の度に技師の白血球数は 健康者の值に近づきつつある.しかし, 調查数の $47.2 \%$ のものは，いずれかの血球数が要注意以下の值にある.

そこで, 施設の管理者はもとより各人においても精密 検査等を行ない，その原因を究明すべきである。

240. 当病院の核医学検查従事者の局所被曝線量

(TLD 素子による測定)

東京女子医科大学病院

荒井一栗原慎一郎・斎藤”忠

廹卦川孝司・金谷、信一

当病院核医学検查に彷事する全從事者の手指の中節部 に, TLD 素子 $\left[\mathrm{BeO}(\mathrm{Na}), \mathrm{CaSO}_{4}(\mathrm{Tm})\right]$ を装着し, 全 從事者の被曝線量, 医師及び技師の被曝線量の比較及び 検查数量との比䩙をした。

全医師では $310 〜 550 \mathrm{mR} /$ 月 となり，1 人当りでは， $167 \sim 300 \mathrm{mR} /$ 月なり，全技師では，220〜320 mR/月と， なり，1人当りでは $55 \sim 80 \mathrm{mR} /$ 月となった。

通常の核医学検査では, 上記の值により放射線作業従 事者は最大許容被曝線量を越えないととがわかった。

\section{1、TLDによる個人被曝線量の管理}

群馬県立がんセンター東毛病院

○羽鳥、昇・羽部孝 山川 勝美・江田 哲雄

当院の個人被曝線量を極光の TLDをもちいて測定し， その結果を昭和 50 年 9 月までの 3 年 6 カ月の線量を集計 した. 対象者は 30 名で， 3 力月ごとの被曝線量は彰断部 に执いて $20 \mathrm{mR}$ 以下，治療部では $25 \mathrm{mR}$ 以下がほとん 
どであったが， RI 部においては $10 \mathrm{mR}$ から $180 \mathrm{mR}$ と 上下に大きなひらきがあった。また集積線量から手診断 部, 治療部と屯，ほほ $200 \mathrm{mR}$ 以下であったが RI 部で は4倍から14倍もの線量を示した。したがって診断，治 療部においては，低被曝線量で作業を行なうととができ るが，RI 部においては線源を近距離で扱うととから， 時間の短縮やより一層の遮蔽物の使用を行ない, 場会に よっては，配置転換などあ考慮する必要がある己思われ ます。

\section{X線撮影の被曝軽減の余地 第 2 報 産婦人科領域について}

\section{千葉大学病院 放射線部}

伊場 䀡三

産婦人科領域のX線撮影は遺伀的と身体的影響が重複 するため，被曝軽減は重要である。乙の領域の撮影術式 部位別件数, 年噛分布を 160 力兹の病院にアンケートを 送り調蕫を行ない，X線像との関係汃ら被曝線量の軽減 の余地を検討した。病院によっては被曝軽減はかなり努 うをなされているが, 高压撮影, 高感度の增感紙フィル ム付加フィルタ一等の使用は多くなった。したがって， 撮影系や画像記録系に今すこし注意を行なえば被戟線量 は現在の1/10〜1/20亿なる.特に骨の輪郭を診断の手掛 りとしている産科のX線診断情報量は LP あたり $1 \mathrm{~mm}$ でも可能である。乙の事は今回の調查で知れた産科の撮 影条件や件数等から洘えると国民線睹の軽減としても大 切である。

\section{3. 胸部撮影の被曝線量軽減策とその臨床応用}

名古屋方立大学病院中央放射線部

○杉山 雅之・川野 誠・池田 保夫

有賀 信喜

竹内 憲彦

胸部撮影では，從来情報容量の増加之被曝線量柽減の ため高圧撮影が良いとされてきた，しかし，遠距誰撮影 グレーデル效果，側方散乱の少い低電尼，小焦点を応用 することによって情報容量が多く，生殖䶃被暴の少い胸 部撮影について実験を試みた。グレーデル效果になるる 入射線量は，管電圧 $80 \mathrm{kV}$ グリッド繁しの方が $140 \mathrm{kV}$ グリッド比100約 5 分の 1 であった。側方散乱線分布は， 女子生殖腺の位置で約10分の1となった，MTFによっ て求めた画質の比較は，1.0〜2.5 $\mathrm{lp} / \mathrm{mm}$ の領域では， エアーギャップ $15 \mathrm{~cm}$ の方がグリッド比 10 ブッキー使 用に比べ良しMTF を示した。同一人物の写真の比較は， 濃度計で行なったが，顕著な差はみられなかった。
この演題群は患者被嚗に留するもの $(236 ， 237 ， 238$ ， $242 ， 243)$ と術者の被曝隹関するもの $(239,240,241)$ に大別される。

演題 236：デンタルトモグラフと一般崡科撮影（口内 法）に打ける皮膚表面線䑁と頭部中心軸の線量を測定し， 被曝軽減からみた場合の前者の有用性について述べたも のである．阪大，花山より測定法についての筫問があっ

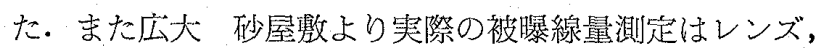
甲状腕等具体的な部位を選定して行なったがよいとのア ドバイスがあった。

演題 237：腰椎側面撮影は他の部位にくらべて高線量 を要し，生殖腚線量も增大する。乙とでは実際の臨床例 から卵䘘の位置的分布を調べ，乙れを壬とにして防護具 を慜作し央用に供している。このような防護具はルーチ ンとして広く使用されるべきであると考える。なお，線 量测定が皮㱆線量し防護具植下だけでなく，卵巣位置 (数点)でもなされていればより説得力のある報告にな ると思われる。

演題 238：胸部之胆のう撮影時の生殖腺被曝線量につ いて検討している．被曝線量軽減と写真の画質は合わせ て論じるべきだと思う。

演題 239：放射線技師の血球数について全国調查を行 ない，それをまとめたものである「白血球数についてみ ると 20〜24歳の群肪最も低り」：亡報告されているが, この原因を解明して頂きたいるのである.

演題 240:RI 検査從事者の手指の被懪線量の䈍を調 查，検討したものである，今後 RI 検查はますます増大 すると思われるので，乙の資料を向とに具体的な防護対 策を講じて頂き，次の機会に発表してほしい.

演題 $241:$ TLDのみを用して倜人被曝線量の管理を行 なり，羍務量との関係について検討している。個人被曝 管理に TLD を使用することに異論はないが，測定値の 譟差の把握, 定期的な校正, また最も一般的なフィルム バッジとの比較等が必要ではないだろうか.

演題 242 ：産婦人科領域の撮影条件についてアンケ一 卜調査を行なった結果，現在の1/10以下に軽減できると している．またX線TV面，瞬時撮影を提唱している。 今後, 卵管造影, 胎児撮影等の具体的な撮影条件につい ても検弪して頂ければありがたい.

演題 243：胸部撮影は高電枉 $(140 \mathrm{kV})$ より低電圧 $(80$ kV)のほうが有利であるとしている。利点のひとつとし て生殖腺線量が少ないとしているが，0.14 mR，0.003 $\mathrm{mR}$ という極微線量領域での1/50が生物学的に意味があ るだろうか，むしろ骨㖪線㽬を考慮すべきではないかと

\section{座長集約}

